\title{
Hipertensi pada Sindrom Metabolik
}

\author{
Syafruddin Haris, * Taralan Tambunan** \\ * Departemen Ilmu Kesehatan Anak, Fakultas Kedokteran Universitas Syiah Kuala-Rumah Sakit Zainoel \\ Abidin, Banda Aceh \\ ** Departemen Ilmu Kesehatan Anak, Fakultas Kedokteran Universitas Indonesia-Rumah Sakit Cipto \\ Mangunkusumo, Jakarta
}

\begin{abstract}
Obesitas merupakan masalah yang banyak dijumpai baik di negara maju maupun di negara berkembang. Seiring dengan meningkatnya kejadian obesitas, dikenal sindrom metabolik yang terdiri dari obesitas sentral, resistensi insulin, hipertensi, dan dislipidemia berupa kadar trigliserida yang tinggi dan kolesterol high density lipoprotein (HDL) yang rendah. Sindrom metabolik terutama disebabkan oleh obesitas dan resistensi insulin. Selain sebagai tempat penyimpanan energi, jaringan lemak juga menghasilkan faktor yang menyebabkan hipertensi. Jaringan lemak dapat menguraikan angiotensin dari sistem angiotensin-renin. Pada obesitas, terjadi resistensi insulin dan gangguan fungsi endotel pembuluh darah yang menyebabkan vasokonstriksi dan reabsorbsi natrium di ginjal dan menyebabkan hipertensi. Penurunan berat badan merupakan faktor penting dalam tata laksana sindrom metabolik dengan hipertensi yang dicapai dengan diet, latihan, medikamentosa atau gabungan hal-hal tersebut. Obat antihipertensi dapat dipertimbangkan sebagai bagian pendekatan holistik dalam tata laksana. (Sari Pediatri 2009;11(4):257-63).
\end{abstract}

Kata kunci: hipertensi, obesitas, sindrom metabolik

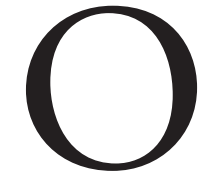

besitas merupakan suatu masalah serius pada masa remaja seperti juga pada orang dewasa. ${ }^{1}$ Akhir- akhir ini terjadi peningkatan jumlah obesitas pada anak dan remaja di negara maju dan berkembang. Seiring dengan peningkatan masalah obesitas, dikenal sindrom metabolik yang terdiri dari obesitas sentral, resistensi insulin, hipertensi dan dislipidemia yang telah

\section{Alamat korespondensi}

Prof. Dr. Taralan Tambunan, Sp.A(K). Divisi Nefrologi. Departemen Ilmu Kesehatan Anak Fakultas Kedokteran Universitas Indonesia. Jl. Salemba no. 6, Jakarta 10430. Telepon: 021-3915179. Fax.021-390 7743. dilaporkan pada orang dewasa. ${ }^{2}$ Terapat hubungan yang kuat antara overweight dan obesitas dengan sindrom metabolik pada anak dan remaja. Perbedaan prevalensi jenis kelamin berhubungan dengan sindrom metabolik, terutama pada anak di bawah usia 10 tahun. Petanda inflamasi dan hemostasis yang meningkat ataupun fibrinolisis yang terganggu, juga berperan dalam sindrom metabolik. ${ }^{1,2}$

Komponen sindrom metabolik dapat muncul pada anak dan remaja seperti pada dewasa, tetapi belum ada kesepakatan mengenai kriteria sindrom metabolik pada anak. ${ }^{1,2,3}$ Beberapa penelitian menggunakan pedoman NCEP (National Cholesterol Educational Program)-ATP III (Adult Treatment Panel III), ${ }^{1,2,3}$ 
sedangkan penelitian lain menambahkan kadar insulin puasa sebagai komponen kriteria sindrom metabolik di samping kriteria sindrom metabolik menurut NCEP-ATP III. ${ }^{2,3}$ Menurut NCEP-ATP III seorang anak dikategorikan mengalami sindrom metabolik apabila memenuhi 3 dari 5 komponen kriteria sindrom metabolik, yaitu (1) obesitas sentral, (2) peningkatan kadar trigliserida, (3) penurunan kadar kolesterol high density lipoprotein (HDL), (4) kadar gula darah puasa terganggu, dan (5) hipertensi., ${ }^{2,3}$ Perubahan dalam pertumbuhan dan perkembangan menyulitkan penentuan nilai batasan komponen kriteria sindrom metabolik (tekanan darah, tinggi badan, berat badan, body mass index (BMI), dan lingkar pinggang) karena berbeda antara anak laki-laki dan perempuan, serta meningkat dengan bertambahnya usia. ${ }^{1}$ Peningkatan tekanan darah dimasukkan ke dalam berbagai kriteria sindrom metabolik, ${ }^{1-5}$ namun hubungannya dengan sindrom metabolik sesungguhnya merupakan hal yang kompleks. ${ }^{4}$

Tujuan penulisan makalah untuk membahas epidemiologi definisi, dan patofisiologi hipertensi pada sindrom metabolik, serta tata laksana.

\section{Epidemiologi}

Prevalensi sindrom metabolik bervariasi berdasarkan kriteria yang digunakan. Pada suatu studi di New Haven yang melibatkan 439 subjek berusia 4-20 tahun, prevalensi sindrom metabolik pada subjek dengan obesitas sedang (BMI z-score 2,0-2,5) 38,7\%, dan subjek dengan obesitas berat (BMI z score $>2,5$ ) 49,7\%. ${ }^{6}$ Prevalensi obesitas meningkat di daerah maju dan berkembang. Tahun 1999 di Amerika Serikat $61 \%$ dewasa mengalami overweight dan obesitas. Sindrom metabolik diperkirakan $22 \%$ dari populasi dewasa di Amerika Serikat. Pada penelitian Bogasa Heart, sindrom metabolik pada remaja di Amerika Serikat 4,2\%, prevalensi pada laki-laki $(6,1 \%)$ lebih tinggi di bandingkan perempuan $(2,1 \%),{ }^{2}$ sedangkan di Jepang $17,7 \%$ anak obesitas mengalami sindrom metabolik. ${ }^{1}$ Di DKI Jakarta, prevalens obesitas meningkat dengan bertambahnya umur. Prevalensi obesitas pada anak berusia 6-12 tahun 4\%, remaja 12-17 tahun 6,2\%, dan remaja berusia 17-18 tahun $11,4 \%$. Kasus obesitas pada remaja lebih banyak ditemukan pada perempuan $(10,2 \%)$ dibandingkan laki-laki $(3,1 \%)^{7}$

\section{Definisi}

\section{A. Body Mass Index (BMI)}

Body mass index (BMI) atau indeks massa tubuh (IMT) adalah indeks sederhana, dan biasa digunakan untuk mengklasifikasikan obesitas pada anak dan dewasa. Indeks ini telah direkomendasikan oleh World Health Organization (WHO) dan The Expert committee on Clinical Guidelines for Overweight in Adolescent Preventive Services sebagai baku pengukuran untuk menentukan obesitas pada anak dan remaja. Body mass index didefinisikan sebagai berat badan (BB) dalam $\mathrm{kg}$ dibagi dengan tinggi badan (TB) dalam $\mathrm{m}^{2}\left(\mathrm{~kg} / \mathrm{m}^{2}\right)$, dan berkolerasi dengan massa lemak tubuh. Dikatakan overweight bila BMI di atas persentil 85 sampai 95 atau BMI $\geq 25 \mathrm{~kg} / \mathrm{m}^{2}$ sedangkan obesitas apabila BMI di atas persentil 95 atau BMI $\geq 30 \mathrm{~kg} / \mathrm{m}^{2}$ berdasarkan umur dan jenis kelamin. ${ }^{8}$

\section{B. Sindrom metabolik}

Kriteria sindrom metabolik pada dewasa mengikuti NCEP /ATP III yang tidak begitu saja diaplikasikan pada anak. ${ }^{1,2,3}$ Yoshinaga $\mathrm{dkk}^{1}$ dalam penelitian tentang sindrom metabolik pada anak mendefinisikannya dengan menyatakan sindrom metabolik bila menemukan 3 dari 5 komponen yang diklasifikasikan yaitu,

1. Hipertensi

2. Kadar kolesterol HDL yang rendah $(<40 \mathrm{mg} / \mathrm{dL})$

3. Kadar serum trigliserida yang tinggi $(>120 \mathrm{mg} /$ $\mathrm{dL})$

4. Kadar glukosa serum puasa yang tinggi $(>100 \mathrm{mg} /$ $\mathrm{dL})$

5. Obesitas sentral ditandai dengan ukuran persentil ke-90 pada lingkar pinggang.

- usia 6-8 tahun anak laki-laki : $>65,1 \mathrm{~cm}$

- usia 6-8 tahun anak perempuan : $>58,5 \mathrm{~cm}$

- usia 9-11 tahun : $>70,2 \mathrm{~cm}$

\section{Hipertensi}

Yoshinaga $\mathrm{dkk}^{1}$ menggunakan kriteria hipertensi sebagai berikut, derajat 1-3 tekanan darah sistolik $\geq 120 \mathrm{~mm} \mathrm{Hg}$ dan tekanan darah diastolik $\geq 70 \mathrm{~mm}$ $\mathrm{Hg}$; derajat 4-5 tekanan darah sistolik $\geq 130 \mathrm{~mm} \mathrm{Hg}$ dan tekanan darah diastolik $\geq 80 \mathrm{~mm} \mathrm{Hg}$. Menurut The Fourth Report on the Diagnosis, Evaluation, and 
Treatment of High Blood Pressure in Children and Adolescents (2004), ${ }^{9}$ definisi hipertensi pada anak adalah apabila tekanan darah sistolik atau diastolik di atas atau sama dengan persentil 95 menurut umur, jenis kelamin, dan tinggi badan.

\section{Patofisiologi hipertensi pada sindrom metabolik}

Definisi sindrom metabolik pada dewasa telah disepakati, namun kontroversi mengenai etiologi yang mendasari sindrom metabolik sampai saat ini masih tetap ada. Hipotesis terbaik menyatakan bahwa obesitas dan resistensi insulin merupakan kunci terjadinya sindrom metabolik. ${ }^{10}$ Obesitas terjadi karena ketidakseimbangan antara asupan energi dengan luaran energi, yaitu asupan energi yang tinggi atau luaran energi yang rendah. Asupan energi tinggi disebabkan konsumsi makanan yang berlebihan, sedangkan luaran energi rendah disebabkan metabolisme tubuh yang rendah, aktivitas fisik, dan efek termogenesis makanan. Kelebihan energi disimpan dalam bentuk jaringan lemak. $^{11,12}$

Hubungan antara obesitas dan hipertensi telah lama diketahui dan telah banyak dilaporkan oleh banyak peneliti, namun mekanisme terjadinya hipertensi akibat obesitas hingga saat ini belum jelas. ${ }^{13}$ Sebagian besar peneliti menitikberatkan patofisiologi tersebut pada tiga hal utama yaitu gangguan sistem autonom, resistensi insulin, serta abnormalitas struktur dan fungsi pembuluh darah. Ketiga hal tersebut dapat saling mempengaruhi satu dengan lainnya. ${ }^{4,13}$
Akhir-akhir ini diketahui bahwa peningkatan kejadian obesitas dan sindrom metabolik terjadi akibat asupan total fruktosa meningkat. Fruktosa seperti gula lainnya menyebabkan peningkatan kadar asam urat dengan cepat. Fruktosa adalah gula biasa yang terdapat pada madu dan buah-buahan. Fruktosa sering ditambahkan pada minuman ringan, kue, permen, dan yogurt. Pemberian fruktosa oral atau intravena dalam waktu 30-60 menit dapat meningkatkan asam urat serum pada manusia dan hal ini dapat berkesinambungan. Glukosa dan gula sederhana lainnya tidak mempunyai efek seperti ini. Di hati, fruktosa akan diubah menjadi fruktosa-11 fosfat dan adenosin triphosphate (ATP) oleh enzim fruktokinase, dan selanjutnya diubah menjadi adenosin diphosphate (ADP). Turunan ADP dimetabolisme menjadi bermacam-macam subtrat purin. Pelepasan fosfat yang cepat bersamaan dengan reaksi adenosin monophosphate (AMP) deaminase. Kombinasi keduanya akan meningkatkan substrat melalui fruktosa oral, dan enzim (deaminase AMP) merupakan regulasi produksi asam urat (Gambar 1). Asam urat yang tinggi dapat mengakibatkan disfungsi endotel dan menurunkan bioavailabilitas nitric oxide (NO) endotel. Gangguan nitric oxide memediasi terjadinya resistensi insulin dan hipertensi. ${ }^{12}$

Peran obesitas dan resistensi insulin pada sindrom metabolik telah banyak dilaporkan. Obesitas sering berhubungan dengan hiperinsulinemia, khususnya tipe android. Laki-laki obesitas cenderung mempunyai deposit lemak di daerah atas tubuh khususnya pada

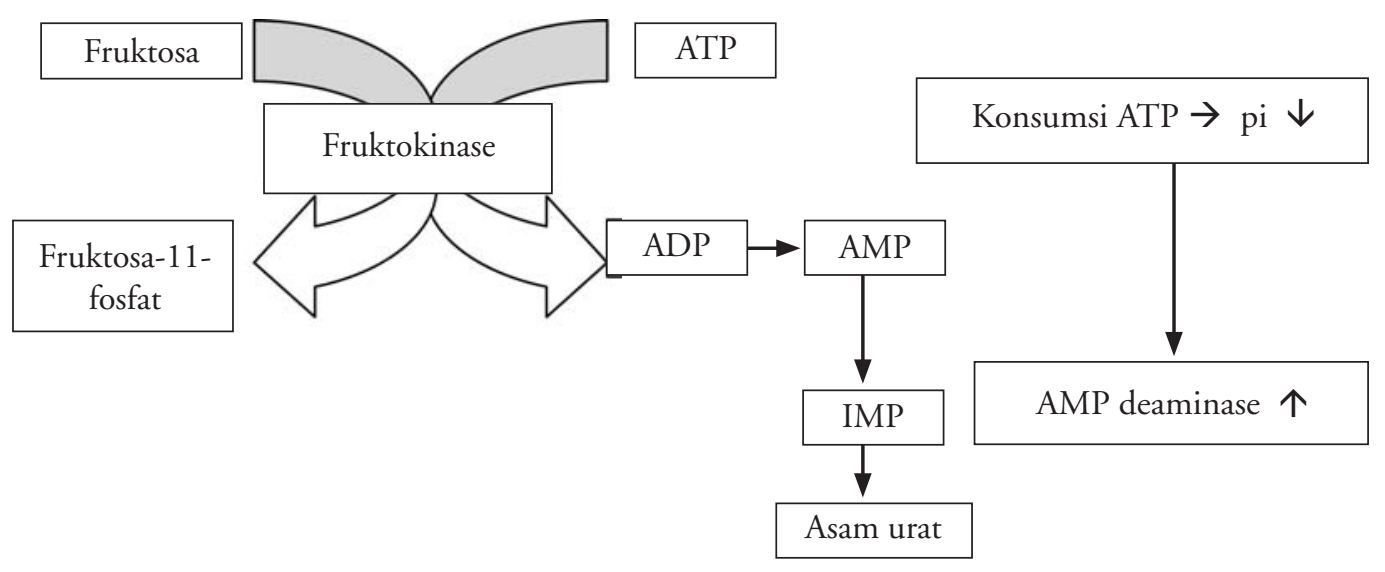

Gambar 1 Fruktosa induksi produksi asam urat di sel hati. ${ }^{12}$ 
tengkuk, leher, bahu, dan perut yang disebut obesitas tipe android. Pada perempuan obesitas dijumpai deposit lemak dengan area yang sama dengan lakilaki meskipun mereka juga mempunyai batas area segmen bawah seperti pada bokong dan pinggul yang disebut obesitas tipe ginekoid. ${ }^{4}$ Pada obesitas tipe android (obesitas sentral), lemak berakumulasi sebagai lemak viseral/intra-abdominal atau lemak subkutan abdomen. Obesitas tipe android berisiko mengalami sindrom metabolik dan penyakit kardiovaskular, khususnya jika terdapat lemak viseral yang berlebihan. Kadar adiponektin yang rendah, adanya resistensi leptin, serta berbagai sitokin yang terlepas dari sel adiposa dan sel inflamasi yang menginfiltrasi jaringan lemak (misalnya makrofag) menurunkan ambilan asam lemak bebas oleh mitokondria pada beberapa jaringan, menurunkan oksidasi asam lemak bebas, dan menyebabkan akumulasi asam lemak bebas intrasel. Kelebihan asam lemak bebas intraselular dan metabolik (fatty acyl CoA, diacyglgycerol, dan ceramide) dapat memicu terjadi resistensi insulin (bahkan hiperisulinemia dan hiperglikemia). ${ }^{11}$

Pada obesitas terjadi resistensi insulin dan gangguan fungsi endotel pembuluh darah yang menyebabkan vasokonstriksi dan reabsorpsi natrium di ginjal yang mengakibatkan hipertensi. ${ }^{14}$ Telah dibuktikan oleh penelitian yang menyatakan retensi garam berhubungan dengan hiperinsulinemia pada obesitas yang menyebabkan hipertensi. Demikian juga insulin dapat meningkatkan produksi norepinephrine plasma yang bermakna yang dapat meningkatkan tekanan darah. Perbaikan tekanan darah dan respons intoleransi glukosa dengan peningkatan aktivitas fisik pada obesitas juga berhubungan dengan penurunan kadar insulin plasma. ${ }^{4}$ Resistensi insulin dapat meningkatkan tekanan darah melalui penurunan nitric oxide yang menimbulkan vasodilatasi, peningkatan sensitivitas garam, atau peningkatan volume plasma. ${ }^{4,5}$

Penelitian lain menunjukkan kecepatan natriuresis dan pengeluaran antinatriuresis sesudah fast have dan memperlihatkan hubungan antara kadar insulin serum dan eskresi garam. Retensi natrium menyebabkan hiperinsulinemia yang indenpenden dari hipoglikemia, laju filtrasi glumerulus (LFG), aliran darah ginjal, atau kadar aldosterol plasma. ${ }^{4}$ Hubungan antara resisten insulin dan tekanan darah pada anak obesitas telah diteliti oleh Umboh dkk. ${ }^{10}$ Sebagian besar anak obesitas menderita pre-hipertensi dan terdapat korelasi linier yang lemah antara kadar insulin dan tekanan darah, serta resistensi insulin mempengaruhi peningkatan tekanan darah sistolik pada anak obese. Pada penelitian ini anak yang obesitas diambil dari anak yang BMI lebih dari persentil ke-95, dan definisi sindrom metabolik tidak disebutkan walaupun beberapa kriteria

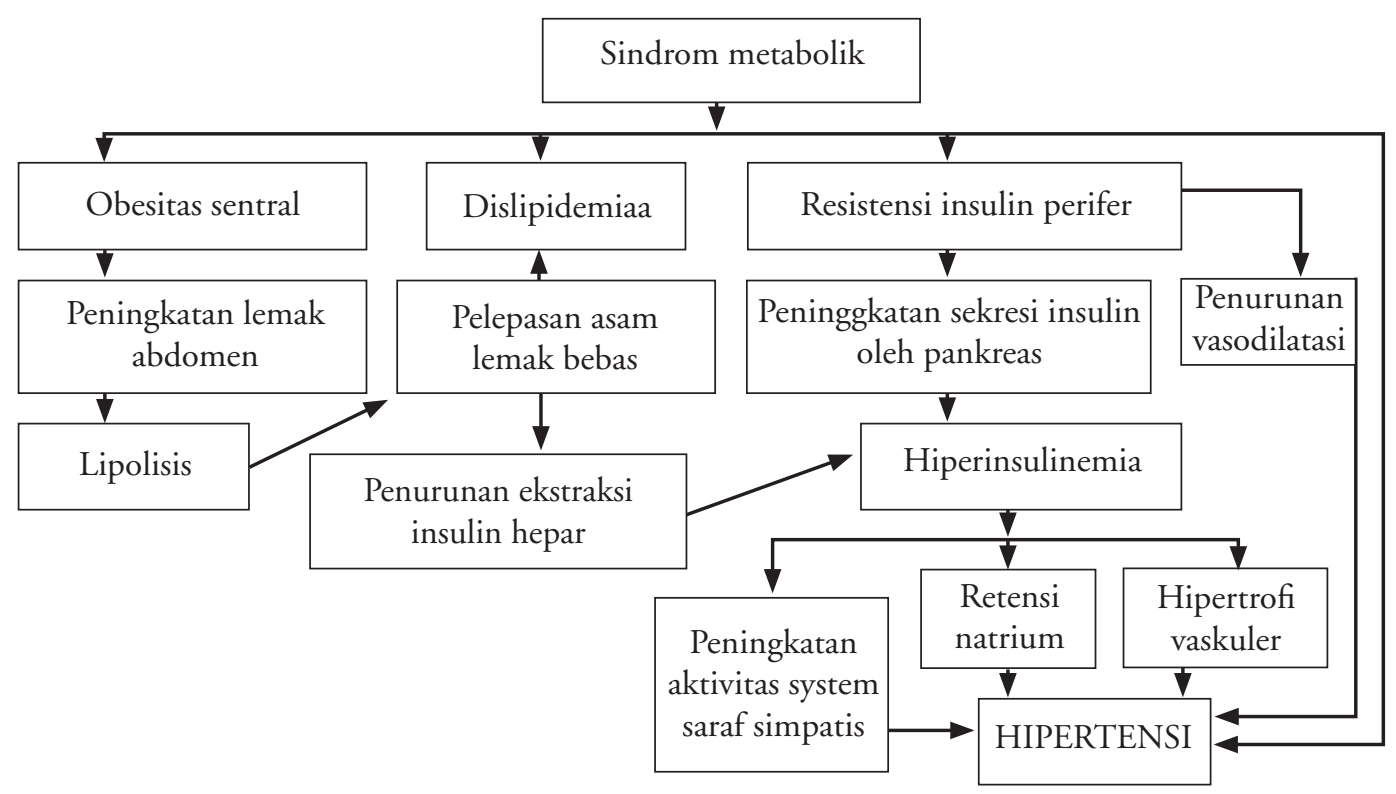

Gambar 2. Patogenesis hipertensi pada sindrom metabolik. ${ }^{11}$ 
sindrom metabolik terdapat pada penelitian ini.

Konsumsi makanan tinggi kalori akan mengakibatkan sindrom metabolik dengan meningkatnya massa lemak di daerah abdomen pada individu yang rentan. Masa lemak abdomen merupakan sumber asam lemak bebas dalam sirkulasi. Penelitian dengan menggunakan model clamp euglycemic hyperinsulinemia menunjukkan efek marker antinatriuretic pada insulin. ${ }^{15}$

Peningkatan masa sel lemak menyebabkan peningkatan produksi angiotensinogen di jaringan lemak, yang berperan penting dalam peningkatan tekanan darah. Sel lemak juga membuat enzim konvertase angiotensin dan katepsin, yang memiliki efek lokal pada katabolisme dan konversi angiotensin. Asam lemak dapat meningkatkan stres oksidatif pada sel endotel dan proses ini diamplifikasi oleh angiotensin. Telah dibuktikan bahwa renin angiotensin system (RAS) pada jaringan lemak terlibat dalam patofisiologi obesitas dan penyakit yang berhubungan dengan obesitas, termasuk hipertensi dan resitensi insulin. Kadar RAS lokal di dalam jaringan lemak berperan dalam meningkatkan aktivitas RAS sistemik, sehingga menyebabkan kenaikan tekanan darah. Jumlah jaringan lemak pada individu dengan obesitas menyebabkan peningkatan RAS dalam jaringan lemak. Selain itu, angiotensin II (komponen utama RAS) dan angiotensinogen (prekursor angiotensin II) berperan dalam pertumbuhan, diferensiasi dan metabolisme jaringan lemak, yang dalam jangka panjang dapat mendorong penyimpanan trigliserida dalam hati, otot rangka, serta pankreas, sehingga menyebabkan resistensi insulin. ${ }^{8}$

Pada obesitas, selain pertambahan masa lemak, masa non-lemak juga meningkat, dan terjadi hipertrofi organ seperti jantung dan ginjal. Pada ginjal terjadi glomerulomegali, vasodilatasi arteriol aferen, dan vasokonstriksi arteriol eferen yang menyebabkan hipertensi intraglomerular. Hipertensi intraglomerular merupakan awal terjadinya mikroalbuminuria dan proteinuria yang selanjutnya melalui berbagai mekanisme selular akan menyebabkan glomerulosklerosis dan fibrosis tubulointertisial pada obesitas. ${ }^{8}$

Peningkatan asupan lemak akan mengubah reabsorpsi natrium di ginjal. ${ }^{8}$ Pada penelitian diketahui bahwa retriksi garam atau gabungan retriksi garam dan pengurangan kalori dapat menormalkan tekanan darah pada perempuan obesitas. Pengurangan kalori yang tidak disertai pengurangan natrium tidak menimbulkan efek hipotensi. Pendapat tersebut dibantah oleh penelitian lain yang melaporkan bahwa tekanan darah turun pada pasien overweight dengan hipertensi yang kehilangan berat badan rata-rata 10,5 kg. Pada observasi, subjek penelitian dan kelompok kontrol mengalami penurunan berat badan disertai penurunan tekanan darah, meskipun kedua kelompok mendapat asupan garam yang tinggi. Sayangnya penelitian tidak melakukan pemeriksaan secara objektif terhadap asupan dan ekskresi garam. ${ }^{16}$ Obesitas berhubungan dengan aktivitas renin-angiotensin, hiperinsulinemia dan peningkatan aktivitas sistem saraf simpatetik, dan semua ini berkontribusi pada reabsorpsi natrium dan berhubungan dengan retensi cairan sehingga menyebabkan hipertensi obesitas renal $^{8,16}$ (Gambar 2).

Manifestasi awal hipertensi pada obesitas diawali oleh hipertensi sistolik tanpa disertai hipertensi diastolik (isolated systolic hypertension). Pada penelitian pengukuran tekanan darah pada remaja dengan obesitas, ditemukan 94\% subjek hipertensi sistolik. Dalam penelitian lain pada kelompok remaja di Amerika Serikat didapatkan bahwa hipertensi sistolik tanpa hipertensi diastolik merupakan faktor risiko terjadinya morbiditas dan mortalitas kardiovaskular pada masa dewasa kelak. ${ }^{2}$ Obesitas selalu dihubungkan dengan terjadinya hipertensi tetapi masih belum begitu jelas kenapa hipertensi tidak terjadi pada semua pasien obesitas. Reade dkk melakukan penelitian pada anak obesitas dengan hipertensi dan yang tidak disertai hipertensi. Dalam penelitiannya, anak obesitas disertai hipertensi cenderung mengalami obstructive sleep apnea syndrome (OSAS) dibandingkan anak obesitas dengan normotensi. ${ }^{17}$ Penemuan ini sesuai dengan hipotesis yang menyatakan bahwa OSAS merupakan salah satu faktor penyebab obesitas yang tidak selalu mengalami hipertensi. ${ }^{18}$

\section{Hubungan hipertensi dengan berat lahir rendah}

Hipertensi adalah komponen sindrom metabolik, dan terjadinya hipertensi pada anak berhubungan dengan berat lahir. Barker $\mathrm{dkk}^{19}$ menyampaikan teori tentang fetal origins hypothesis, yaitu bahwa janin melakukan adaptasi sebagai respons terhadap kekurangan nutrisi, mengakibatkan perubahan metabolisme dan sruktur organ yang menetap. Terdapat hubungan berat lahir rendah dengan terjadinya penyakit kronik di kemudian hari, seperti penyakit jantung koroner, diabetes tipe 2, dan hipertensi. Janin beradaptasi terhadap kekurangan nutrisi selama masa kehamilan dengan 
cara menyesuaikan program sel pada saat periode kritis perkembangan intrauterin, yang bermanifestasi sebagai disfungsi organ sistemik. Setelah lahir, efek vaskular yang bersifat protektif pada saat intrauterin menjadi maladaptif pada saat nutrisi neonatal membaik. Hal ini dapat terjadi pada bayi yang awalnya mempunyai kecenderungan untuk kejar tumbuh hingga terjadi obesitas pada masa dewasanya.

Obesitas yang terjadi berupa obesitas sentral yaitu lemak berdistribusi di daerah perut depan yang dapat berlanjut menjadi resistensi insulin dan hipertensi. Pada penelitian dengan menggunakan baku emas model clamp euglycemic hyperinsulinemia yang dilakukan pada usia 70 tahun, didapatkan bahwa resistensi insulin terdapat hanya pada BMI yang tinggi pada subjek yang diteliti dengan riwayat bayi berat lahir rendah (BBLR). Faktor lain yang berperan pada BBLR adalah jumlah nefron yang sedikit sehingga secara umum terjadi penurunan jumlah nefron sesuai ukuran tubuh selama nefrogenesis dan sangat berhubungan dengan berat badan lahir. ${ }^{20}$ Menurut Brenner dan Cherton, ${ }^{21}$ hipertensi terjadi sebagai respons penurunan jumlah nefron ginjal pada orang yang lahir dengan BBLR. Jumlah nefron yang rendah merupakan faktor risiko terjadinya cedera ginjal sehingga terjadi hipertensi. Penurunan jumlah nefron mengakibatkan peningkatan tekanan kapiler glomerulus dan hiperfiltrasi glomerulus. Dilatasi arteri aferen secara bersamaan akan merespon transmisi langsung dinding kapiler glumerulus. Proses ini dapat menyebabkan glomerulosklerosis yang menetap. Pada penelitian cross sectional, dilakukan pemeriksan ginjal bayi berat lahir normal yang meninggal bukan disebabkan oleh penyakit ginjal dibandingkan dengan ginjal bayi BBLR yang usia gestasinya sama. Pada bayi BBLR didapat penurunan jumlah glomerulus. ${ }^{21}$ Kecepatan pertambahan berat badan dapat juga mengeksaserbasi cedera glomerulus disebabkan besar tubuh memaksa peningkatan beban ekskresi. ${ }^{19}$ Penelitian di Carolina Selatan, membuktikan bahwa terdapat respon terapi yang berbeda di antara pasien yang dihubungkan dengan berat lahir. Pasien hipertensi yang lahir dengan BBLR lebih responsif dengan terapi lini kedua dibandingkan dengan pasien hipertensi yang lahir dengan berat lahir normal. ${ }^{19}$

\section{Pengobatan hipertensi}

Kejadian hipertensi meningkat pada anak yang obesitas, umumnya terdapat pada remaja dengan kombinasi faktor risiko kardiovaskular, riwayat keluarga maupun etnik untuk terjadinya hipertensi. ${ }^{22,23}$ Perjalanan klinis hipertensi dengan obesitas berawal dari karekteristik tekanan darah sistolik yang meningkat. Hipertensi sistolik merupakan faktor risiko terjadinya kesakitan dan kematian pada kardiovaskular seperti dilaporkan pada pasien dewasa. ${ }^{22,23}$

Dalam tata laksana hipertensi, beberapa penelitian menganjurkan untuk menurunkan berat badan. Penurunan berat badan diikuti dengan diet dan latihan merupakan terapi primer pada hipertensi dengan obesitas. ${ }^{24}$

Hipertensi persisten terindikasi mendapat terapi farmakologi karena berhubungan dengan faktor risiko diabetes tipe 1 dan 2, hipertensi yang mengganggu organ target atau organ lainnya. Pada keadaan seperti ini dipertimbangkan penggunaan obat antihipertensi dosis tunggal dan diawali dengan dosis rendah. Pengobatan hipertensi pada anak menggunakan $A C E$ inhibitor, angiotensin receptor blockers, B-blockers, calcium chanel blockers, dan diuretik. Terapi antihipertensi spesifik dapat dilakukan dengan melihat penyakit yang mendasarinya atau kondisi medik yang terjadi bersamaan. Sebagai contoh, penggunaan $A C E$ inhibitor, angiotensin receptor blocker pada diabetes dengan mikroalbuminuria atau dengan proteinuria. Pada penelitian Douglas dkk, (dikutip dari Matthews dan Solomon ${ }^{24}$ ) yang memberikan obat anti hipertensi pada hipertensi primer dan sekunder berupa CCB (calcium-channel blockers) yang terdiri dari amlodipin dan nifedipin serta $A C E$ inhibitor yang terdiri dari enalapril dan kaptopril yang pada akhirnya menyatakan pilihan obat anti hipertensi tergantung pada etiologi hipertensi tersebut. Pada pasien hipertensi yang disertai penyakit yang mendasarinya, dengan mempertimbangkan manfaat penurunan proteinuria pada pasien dengan penyakit glomerular atau malformating renalis, sebaiknya dipertimbangkan pemberian $A C E$ inhibitor.

Untuk anak yang tidak disertai komplikasi primer hipertensi dan tidak mengganggu organ target, tekanan darah dapat dicapai kurang dari persentil ke-95 berdasarkan jenis kelamin, umur, dan tinggi badan sedangkan pada anak dengan gagal ginjal kronik, diabetes, atau dengan gangguan organ target, tekanan darah diharapkan mencapai kurang dari persentil ke-90 berdasarkan jenis kelamin, umur dan tinggi badan. ${ }^{22}$ Disimpulkan bahwa obesitas dan resistensi insulin merupakan komponen penting 
yang mendasari sindrom metabolik. Hipertensi pada sindrom metabolik terjadi melalui beberapa faktor yaitu peningkatan aktivitas saraf simpatis, peningkatan aktivitas sistem renin angiotensi, serta gangguan vasodilatasi. Kombinasi hipertensi dan komponen sindrom metabolik akan meningkatkan timbulnya kerusakan organ target dan kejadian penyakit kardiovaskular, serta mortalitas.

\section{Daftar Pustaka}

1. Yoshinaga M, Tanaka S, Shimago A, Sameshima K, Nishi J, Nomura Y, dkk. Metabolic syndrome in overweight and obese Japanese children. Obesity Research 2005;13:1135-40.

2. Cruz ML, Goran MI. The metabolic syndrome in children and adolescents. Current Diabetes Report 2004;4:53-62.

3. Sun SS, Grave DG, Siervogel MR, Pickoff AA, Arslanian SS. Systolic blood pressure in childhood predicts hypertension and metabolic syndrome later in life. Pediatrics 2007;119:237-46.

4. Dornfeld LP, Maxwell MH, Wals A, Tuck M. Mechanisms of hypertension in obesity. Kidney Int 1987;22:254-8.

5. Robinson RF, Batisky DL, Hayes JR, Nahata MC, Mahan JD. Body mass index in primary and secondary pediatric hypertension. Pediatr Nephrol 2004;9:1379-84.

6. Weiss R, Dziura J, Burgert TS, Tamborlane WV. Obesity and metabolic syndrome in children and adolescents. N Engl J Med 2004;350:2362-74.

7. Soedibyo S, Firmansyah A, Djer MM. Prevalence and influencing factors of obesity in elementary school pupils. Pediatr Indones 1998;38:193-204.

8. Aneja A, El-Atat F, McFarlane IS, Sowers RJ. Hypertension and obesity. Diunduh dari http://rphr. endojournal.org. Diakses tanggal 09 April 2007.

9. National High Blood Pressure Education Program Working Group on High Blood Pressure in Children and Adolescents. The fourth report on the diagnosis, evaluation, and treatment of high blood pressure in children and adolescents (2004). Pediatrics 2004;114:55576.

10. Umboh A, Kasie J, Edwin J. Hubungan antara resistensi insulin dan tekanan darah pada anak obese. Sari Pediatri 2007;8:289-93.

11. Yogiantoro M. Hypertension and insulin resistance. Dalam: Makalah lengkap The $6^{\text {th }}$ Jakarta nephrology \& hypertension course and symposium on hypertension. Pernefri;2006.h.103-115.

12. Nakagawa T, Tuttle KR, Short RA, Johnson RJ. Hypothesis: fructose-induced hyperuricemia as a causal mechanism for the epidemic of the metabolic syndrome. Nature Clin Pract Nephrol 2005;1:80-6.

13. Sinaiko AR, Steinberger J, Moran A, Prineas RJ, Vessby $\mathrm{B}$, Basu dkk. Relation of body mass index and insulin resistance to cardiovascular risk factors, inflammatory factors, and oxidative stress during adolescence. Circulation 2005;111:1985-91.

14. Manunta P, Bianchi G. Low-salt diet and diuretic effect on blood pressure and organ damage. J Am Soc Nephrol 2004; 15:43-6.

15. Krikken JA, Lely AT, Bakker SJL, Navis G. The effect of a shift in sodium intake on renal hemodynamics is determined by body mass index in healthy young men. Kidney Int 2007;71:260-5.

16. Alderman MH. Dietary sodium and cardiovascular health in hypertensive patients: the case against universal sodium restriction. J Am Soc Nephrol 2004;15:47-50.

17. Reade EP, Whaley C, Lin JJ, McKenney DW, Lee D, Perkin R. Hypopnea in pediatric patients with obesity hypertension. Pediatr Nephrol 2004;19:1014-20.

18. Croix B, Feig DI. Chilhood hypertension is not a silent disease. Pediatr Nephrol 2006;21:527-32.

19. Barker DJP, Bagby SP, Hanson MA. Mechanisms of disease: in utero programming in the pathogenesis of hypertension. Nature Clin Pract Nephrol 2006;2:700-7.

20. Wilkin TJ, Metcalf BS, Murphy MJ, Kirkby J, Jeffery AN, Voss LD. The relative contributions of birth weight, weight change, and current weight to insulin resistance in contemporary 5-year-olds. Diabetes 2002; $51: 3468-72$.

21. Brenner BM, Chertow GM. Congental oligonephropathy and the etiology of adult hypertension and progressive renal injury. Am J Kidney Dis 1994;71:260-65.

22. Mallare JT, Karabell AH, Mieyer PV, Stender SRS, Christensen ML. Current and future treatment of metabolic syndrome and type 2 diabetes in children and adolescents. Diabetes Spectrum 2005;18:220-8.

23. Siverstein DM, Champoux E, Aviles DH, Vehaskari VM. Treatment of primary and secondary hypertension in children. Pediatr Nephrol 2006;21:820-7.

24. Matthews KA, Salomon K. Hostility predicts metabolic syndrome risk factors in children and adolescents. Health Psy 2003;3:279-86. 